\title{
EDITORIAL
}

\section{Conservation of the tea (Camellia sinensis (L.) O. Kuntze) ecosystem through enhancement of natural enemies of pests}

\author{
Bhabesh Deka $^{1 *}$, Azariah Babu ${ }^{1}$, Chittaranjan Baruah ${ }^{2}$, Suman Sarkar ${ }^{1}$ and Dhirendra K Sharma ${ }^{3}$ \\ ${ }^{I}$ Department of Entomology, Tea Research Association, North Bengal Regional $R$ \& D Centre, Nagrakata, \\ Jalpaiguri, West Bengal - 735225, India \\ ${ }^{2}$ Postgraduate Department of Zoology, Darrang College (Gauhati University), Tezpur- 784001, Assam, India \\ ${ }^{3}$ School of Biological Science, University of Science \& Technology, Meghalaya - 793101, India
}

Tea (Camellia sinensis (L.) O. Kuntze), being its perennial and monoculture nature, provides a stable microclimate for various insect pests, which cause substantial loss of crop (Li et al., 2019). With the escalating cost of insect pest management and increasing concern about the adverse effects of the pesticide residues in manufactured tea, there is an urgent need to explore other avenues of alternate pest management strategies (Babu, 2011). In general, the tea plantations provide a stable microclimate and food supply for several notorious pests, such as insects, mites, and nematodes, etc. They also support an array of natural enemies in the ecosystem. Although there are numerous non-conventional methods available, pest control in the tea ecosystem was mainly achieved by the use of synthetic pesticides until today. Biological pest control methods are adopted globally in major crops to avoid the negative impact of synthetic pesticides (Gillespie et al., 2000). Several tea pests may be controlled by using natural enemies as biological control agents in an integrated pest management approach (Babu et al., 2011).

The natural enemy guild is dominated by predators in several ecosystems. Muraleedharan and Roy (2016) reported a total of 200 predatory arthropod species were recorded in the tea ecosystem. The overall species composition reflects the richness of arthropod natural enemies, i.e., predators and parasitoids of tea pests, where the natural enemy to pest ratio is $1.7: 1$. The tea plantations in Northeast India harbour several species of coccinellids, such as Cryptogonus bimaculatus, Juravia quandrinotata, J. opaca, Menochilus sexmaculatus, and Stethorus gilvifrons, which feed on eriophyid mites, spider mites, aphids, and scale insects (Somchoudhury et al. 1995). The parasitoids, Apanteles coedicius, Trioxys indicus, and Aphidus colemani, have several hosts, like Toxoptera aurantii feeding on tea, and Aphis gossipii and Aphis craccivora on weeds in tea fields. The tea mosquito bug $H$. theivora are being preyed upon by Chrysoperla carnea, Oxyopes sp., Plexippus sp., Phidippus sp., and Scymnus sp. and mantids. Eggs of H. theivora were found parasitized by Erythmelus helopeltidis Gahan in South India (Sudhakaran and Muraleedharan, 2006). The activities of predators and parasitoids have been found to be high in Northeast India. In the areas of North Bengal, Roy et al. (2005) found 35 species of spiders and 25 species of coccinellids as natural enemies in the tea ecosystem, while 94 species of predators and 33 species of parasitoids were reported from the sub-Himalayan tea plantations of North Bengal, among which the predators, spiders and ladybird beetles, and among the parasitoid groups, Braconidae and Ichneumonidae, were dominant (Das et al. 2010).

\section{Sycanus collaris (Fabricius):}

Reduviidae a large family that belongs to the order Hemiptera, are found to be efficient predators of different insect pests, preferably lepidopteran larvae (Ambrose et al., 2009). Sycanus collaris, (Fabricius), known as the assassin bug, all of its life stages efficiently feed on the target insect. The sequential predatory behaviour of the genus Sycanus on its prey is very active (Ambrose et al., 2009). S. collaris is found to feed on different hosts, like the tea red slug caterpillar, Eterusia magnifica (Butler) as well as the pupal stage of the tea looper, Hyposidra talaca Walker. During the winter period (December to February), when the tea plants are subjected to pruning, S. collaris forages for food and shelter in the un-pruned plots and shade trees. They preferred to shelter in small jungle trees associated with tea fields. The voracious predatory behaviour of $S$. collaris effectively prevented the increasing population density of $H$. talaca under field conditions. Sarkar et al., (2019). Sarkar et al., (2019) reported the predatory efficiency of $S$. collaris on the larvae of $H$. talaca and reconfirmed that the larger size of life stage $S$. collaris preferred by the later stages (IV and V instar larvae) to fulfill the nutritional requirements. Predatory behaviour of feeding preference highlights the vital role of this predator as an efficient biological control agent in the tea ecosystem. Conservation of this predator in the plantation belt would be useful in developing a bio-control-based looper pest management strategy in the tea ecosystem.

\section{Eocanthecona furcellata (Wolff):}

The stink bug, Eocanthecona furcellata (Wolff) is one of the important predator that has recently included in the field of biological control due to its potential to prey different orders of insect pests such as, lepidoptera, 
coleoptera and heteroptera (De Clercq, 2000). Das et al. (2010) reported the presence of this predatory stink bug in tea ecosystem. Chakravarty et al. (2017) observed that higher temperatures and cloudy conditions favored the population dynamics of this stink bug. Earlier studies on seasonal abundance of E. furcellata showed that its occurrence was coinciding with the cyclic oscillations of the looper (H. talaca) population. Statistically significant correlation and regression values with all the abiotic factors indicated that, the populations of E. furcellata can easily build-up in tea ecosystem. The survival fitness of this stink bug and fecundity rate confirmed the possibility of maintaining and mass rearing of this predator under laboratory conditions.

\section{Stethorus aptus (Kapur):}

The ladybird beetles have gained considerable significance in biological control in several agro-ecosystems. The predatory nature of most coccinellid beetles makes them economically important. They have the capacity to search and feed ravenously on larval and adult stages of aphids, mites and other soft-bodied arthropods (KimKyuchin et al. 2000). In recent years, the introduction of indigenous natural enemies has been more favored than exotic predators for efficient biocontrol and to reduce undesirable ecological problems (Brader, 1980). In this regard, the predacious ladybird beetles are widely used in biocontrol as the majority of them feed on different tea pests (Muraleedharan et al., 2001). This coccinellid beetle, Stethorus aptus (Kapur), has been recorded for the first time in the tea growing areas of the north east region (Barua et al., (2013). Barua et al., (2013) while studying the $S$ aptus in the tea ecosystem in order to evaluate their potential against the tea red spider mite, reported that the predatory efficiency of this Coccinellidae beetle was found to increase with advancement of larval instars. The fourth larval instar of the beetle was found to be more voracious than the other larval instars. (Barua et al., 2013). In general, it is well established that most Stethorus species are considered to be 'high density predators', since they require abundant prey (McMurtry and Johnson 1966). Barua et al., (2016) reported that all the stages of the red spider mite were predated by $S$. aptus. However, prey preference varied among the larval stages of $S$. aptus. The high rate of consumption by $S$. aptus adults suggests that this species has certain advantages as a potential biocontrol agent due to its high longevity, dispersal characteristics, and ability to locate host density areas.

\section{Cotesia ruficrus (Haliday):}

Braconid wasps as promising parasitoids are being considered as potential natural enemies in several agroecosystems (Rahman and Bhola 2011). Endoparasitoid belonging to the family Braconidae lay eggs and complete their larval period inside a suitable host insect (Jung et al. 2006). They usually prefer healthy larvae of lepidopteran pests. This kind of parasitism affects the fitness of the host larvae and ultimately leads to mortality. Generally, the growth of the larvae of the parasitoid and developmental duration depend on the host's fitness, stage, and physiological condition (Kim et al. 2006). Parasitizatism by the braconid wasp alters the host's normal feeding and movement. Cotesia ruficrus Haliday is found to be one of the effective parasitoid wasps which attack the tea looper complex (Das et al., 2010). Several innovative research works have been done on the host-parasite interaction between C. ruficrus and Cnaphalocrocis medinalis (Chen et al., 2016). The parasitoid, Cotesia spp, was reported to be an efficient parasitoid on its selected host, $H$. talaca, consequently leading to the death of the host (Das et al., 2010). Just after emerging from the host, the larvae of the parasitic wasp construct pupal cocoons and, after a few days, the adults emerge (Potting et al., 1997). Sarkar et al., (2020) while studying the stage specificity for successful parasitism by $C$. ruficrus by providing different host larval instars of $H$. talaca. The highest percentage of parasitisms of almost $74 \%$ with the maximum number of pupal cocoons was recorded from the fourth instar host larvae. The female wasps show more preference towards the fourth instar host larvae of $H$. talaca. More successful parasitization may be attributed to the large body size, which could be more suitable for the developing larvae inside the host. Similar parasitic activities were also reported earlier by Chen et al. (2016) on the host selection of C. ruficrus and reported more than $60 \%$ successful parasitism by $C$. ruficrus on fourth instar host larvae, which indicated their ability to regulate the population of this major tea pest in the tea ecosystem. The host-parasitic interaction between $C$. ruficrus and $H$. talaca might be helpful in developing an IPM component for eco-friendly management.

\section{Mallada boninensis (Okamoto):}

The green lacewing, Mallada boninensis (Okamoto), is also an important predator of a variety of softbodied arthropods, including red spider mites found in tea. Green lacewings have been frequently suggested for biological control efforts in recent years (Singh and Jalali, 1991). The larvae feed on spider mites, early caterpillars, scales, and aphids, etc., infesting a variety of plants. Adults eat mostly nectar, pollen, and honeydew, but a few are predatory (McEven et al. 2001). The green lacewing has been described as an efficient predator of red spider mites infesting tea, and its biology and predatory capabilities on red spider mites have been examined (Babu et al., 2011; Vasanthakumar et al., 2012).

\section{Chrysoperla carnea( Stephens):}

Chrysoperla carnea (Stephens), the common green lacewing is an important generalist predator (Sarwar, 2014) and is best known as a biocontrol agent (Menon et al., 2015). The larval stage is a more voracious feeder of soft-bodied insects such as tea mosquito bugs, aphids, whiteflies, mealy bugs, thrips, mites, leaf hoppers, jassids, caterpillars, and insect eggs (Sarwar and Salman, 2016). However, aphids are the more preferred hosts (Solangi et al., 2013). The adults are free living and they only feed on honey, pollen and 
water (Nadeem et al., 2014). The ability of $C$. carnea to be exploited as a biocontrol agent in the IPM program (Memon et al., 2015).

Natural enemies are subjected to continuous deterioration in populations, especially in modern agricultural systems characterized by complete removal of plants after harvesting as well as by frequent application insecticides. The practice of complete removal of plants gives rise to the elimination of natural enemies after each crop season. Conservation biological control is the protection of natural enemies against adverse effects of pesticides and incompatible cultural practices, and improving their efficiency by providing food sources.

The maximum of natural control is an essential concept of integrated pest management. Thus, temporal variations in arthropod abundance, variety, species richness, and community structures are key factors to consider when developing different pest management methods. Arthropod species invade tea plantations once they are planted, and their variety grows over time. The environment, cultivars, cropping patterns, and production techniques all influence their communities. In situ protection and preservation of natural enemies in the tea ecosystem, as well as a decrease in the use of pesticides, are desirable in order to accomplish the goal of producing exportquality tea: a biorational approach to tea production. As seen by comparing research on natural enemy diversity between organic (high diversity index) and pesticidetreated conventional tea gardens, large-scale and indiscriminate applications of broad-spectrum organo-synthetic insecticides for pest control destroy natural enemies (Das et al. 2005). The basic aim of conservation biological control (CBC) would be to protect, maintain, and improve the efficacy of the current population of natural enemies by using environmentally benign methods and reducing pesticide use (Jonsson et al. 2008). Plant diversification programmes assist inhabitant manipulation by inter-cropping with shade trees and cover planting un-occupied areas in tea plantations, which may aid the $\mathrm{CBC}$ process by providing shelter, nectar, pollen (Wackers et al. 2007), and alternate host/prey for natural enemies (Zehnder et al. 2007). Conservation of the tea ecosystem through preserving and enhancing natural enemies provides alternatives to chemical pesticides.

\section{REFERENCES}

Ambrose, D. P., Rajan, X. J. S., Nagarajan, K., Singh, V. J. and Krishnan, S.S. 2009. Biology, behaviour and functional response of Sphedanolestes variabilis Distant (Insecta: Hemiptera: Reduviidae: Harpactorinae), a potential predator of lepidopteran pests. Entomologia Croatica.13(2): 33-44.

Babu, A., Vasantha Kumar, D., Jasin Rahman, V.K., Roobakkumar, A. and Sundaravadivelan C. 2011. Potential of Mallada boninensis Okamoto
(Neuroptera: Chrysopidae), as a biocontrol agent of Oligonychus coffeae Nietner (Acarina:Tetranychidae) infesting tea J. Plantation Crops. 39(1), 193-195.

Barua A, Babu A, Rajkhowa RC. 2013. Study on life cycle parameters of Stethorus aptus (Kapur) (Coleoptera: Coccinellidae): a new predator of tea red spider mite Oligonychus coffeae (Nietner) (Tetranychidae). 2 (12). International journal of scientific research. 566- 567

Barua A., Babu A. \& Rajkhowa R.C. 2016. Seasonal Abundance and Predatory Potential of Stethorus aptus Kapur (Coleoptera: Coccinellidae): A Biocontrol Agent of Tea Red Spider Mite Oligonychus coffeae Nietner (Acarina: Tetranychidae). Proc Zool Soc71, 224-228. https://doi.org/10.1007/s12595-016-0197-4

Brader L. 1980. Advances in applied entomology. Annals of Applied Biology, 94: 349-365.

Chakravarty S., Agnihotri M., \& Jagdish J. 2017. Seasonal abundance of predatory bugs, Eocanthecona furcellata (Wolff.) and Rhynocoris fuscipes (F.) and its olfactory responses towards plant and pest mediated semiochemical cues in Pigeonpea ecosystem. Legume Research, 40(2), 351-357.

Chen Y., Liu X.G., Wang J., Zhao J., Lu Z.X., Liu Y.H. 2016. Cotesia ruficrus (Hymenoptera: Braconidae) parasitizing Cnaphalocrocis medinalis (Lepidoptera: Pyralidae): developmental interactions and food utilization efficiency of hosts. J Econ Entomol. 109(2):588-593.

Das S., Mukhopadhyay A., Roy S. 2010. Morphological diversity, developmental traits and seasonal occurrence of looper pests (Lepidoptera: Geometridae) of tea crop. J Biopest. 3:16-19.

Das S.C., Sarker M., Mukhopadhyay A. 2005. Changing diversity of hymenopteran parasitoids from organically and conventionally managed tea ecosystem of North Bengal. Indian J Environ Biol 26(3):505-509

De Clercq, P. 2000. Predaceous stinkbugs (Pentatomidae: Asopinae). In: Heteroptera of economic Importance. Boca Raton. Florida, CRC Press. 758-761.

Gillespie D.R., Opit G., Roitberg B. 2000. Effects of temperature and relative humidity on development, reproduction and predation in Feltiella acarisuga (Vallot) (Diptera: Cecidomyiidae). Biological Control, 17: 132-138.

Jonsson M., Wratten S.D., Landisn D.A., Gurr G.M. 2008. Recent advances in conservation biological control of arthropods by arthropods. Biol Control 45:172-175

Jung S., Kwoen M., Choi J.Y., Je Y.H., Kim Y. 2006. Parasitism of Cotesia spp. enhances 
susceptibility of Plutella xylostella to other pathogens. J Asia Pac Entomol. 9(3):255-263.

Kim Y., Ibrahim A.M.A., Jung S., Kwoen M. 2006. Differential parasitic capacity of Cotesia plutellae and $C$. glomerata on diamondback moth, Plutella xylostella and dichotomous taxonomic characters. J Asia Pac Entomol. 9(3):293-300.

Kim-Kyuchin, Choi-Ducksoo, Kim K.C., Choi D.S. 2000. Natural enemies of citrus red mite, Panonychus citri McGregor and seasonal occurrence of major predators on Yuzu tree (Citrus Junos). Korean Journal of Applied Entomology, 39(1): 13-19.

Li J., Zhou Y., Zhou B., Tang H., Chen Y., Qiao X., \& Tang J. 2019. Habitat management as a safe and effective approach for improving yield and quality of tea (Camellia sinensis) leaves. Scientific reports 9(1): 433. DOI:10.1038/s41598-018-36591$\mathrm{X}$

McEwen P.K., New T.R. and Whittington A. 2001. Lacewings in the Crop Environment. Cambridge University Press, Cambridge, UK: 546.

McMurtry J.A., and H.G. Johnson. 1966. An ecological study of the spider mite Oligonychus punicae (Hirst) and its natural enemies. Hilgardia 37: 363 402.

Memon A.S., Omar D., Muhamad R., Sajap A.S., Asib N. and Gilal A.A. 2015. Functional responses of green lacewing, Chrysoperla nipponensis (Neuroptera: Chrysopidae) reared on natural herb based artificial diet. Journal of Entomology and Zoology studies 3(6): 80-83.

Muraleedharan, N., Selvasundaram, R. and Radhakrishnan, B. 2001. Parasitoids and predators of tea pests in India. Journal of Plantation Crops, 29 (2): $1-10$.

Muraleedharan N., Roy S. 2016. Arthropod pests and natural enemy communities in tea ecosystems of India. A.K. Chakravarthy, S. Sridhara (eds.), Economic and Ecological Significance of Arthropods in Diversified Ecosystems, DOI 10.1007/978-98110-1524-3_18

Nadeem S., Hamed M., Ishfaq M., Nadeem M.K., Hasnain M., and Saeed N.A. 2014. Effect of Storage Duration And Low Temperatures On The Developmental Stages Of Chrysoperla carnea (Stephens) (Neuroptera: Chrysopidae). The Journal of Animal \& Plant Sciences 24(5): 1569-1572.

Potting R.P.J., Overholt W.A., Danso F.O. and Takasu K. 1997. Foraging behaviour and life history of the stemborer parasitoid Cotesia flavipes (Hymenoptera: Braconidae). Journal of Insect Behaviour, 10: 13-29.

Rahman A. and Bhola R.K. 2011. Role of kairomone in parasitization efficiency of larval parasitoid Apanteles taprobene Cameron (Hym: Braconidae), in Buzura suppressaria a Lepidopteran Pest of Tea. Science\& Culture, 77 (9-10): 416-418.
Roy S., Talukdar T., Saha A.S., Banerjee D.K., Sannigrahi S, Gurusubramanian G. 2005. Species richness and seasonal abundance of spider and lady bird fauna in tea eco-system of North Bengal. In Proceedings of $34^{\text {th }}$ Tocklai Conference, Tea Research Association, Tocklai Experimental Station, Jorhat, pp. 347-351

Sarkar S., Babu A., Chakraborty K. and Deka B. 2019: Study on the Biology, Feeding Behaviour and predatory Potential of Sycanus collaris (Fabricius) (Heteroptera: Reduviidae), a new Predator of Hyposidra talaca (Walk.) (Lepidoptera: Geometridae), a major Tea pest and mass Rearing on Corcyra cephalonica (Stainton) in Laboratory'. International Journal of Current Advanced Research, 08(06), pp. 19258-19262. DOI: http://dx.doi.org/10.24327/ ijcar.2019.19262.3705

Sarkar S., Babu A., Chakraborty K. and Deka B. 2020. Biology and life history of Cotesia ruficrus (Hymenoptera: Braconidae) a potential parasitoid of Hyposidra talaca (Lepidoptera: Geometridae) larvae, a major tea pest. Journal of Biopesticides, 13(1):79-84.

Sarwar M. 2014. The propensity of different larval stages of lacewing, Chrysoperla carnea (Stephens) (Neuroptera: Chrysopidae) to control aphid, Myzus persicae (Sulzer) (Homoptera: Aphididae) evaluated on Canola, Brassica napus L. Songklanakarin J Sci Technol 36(2): 143-148.

Sarwar M. and Salman M. 2016. From Production to Field Application Methodology of Generalist Predator Green Lacewing, Chrysoperla carnea [Stephens] (Neuroptera: Chrysopidae). International Journal of Zoology Research 1(1):3540.

Singh S.P. and Jalali S.K. 1991. Chrysopid predators, their mass production and use. Extension Bulletin No.2, Biological Control Centre, NCIPM, Faridabad: 12.

Solangi A.W., Lanjar A.G., Baloch N., Rais M.U.N. and Khuhro S.A. 2013. Population, host preference and feeding potential of Chrysoperla carnea (Stephens) on different insect host in cotton and mustard crops. Sindh Univ Res Jour (Sci sre) 45(2): 213-218.

Somchoudhury A.K., Saha K., Sarkar P.K., Choudhary A., Bhattacharya A. 1995. Approaches to integrated control of red spider mite, Oligonychus coffeae (Nietner) on tea. In Proce.1995 Int. tea Quality - Human Health Symposium, Shanghi, China.

Sudhakaran R., Muraleedharan N. 2006. Biology of Helopeltis theivora (Hemiptera: Miridae) infesting tea. Entomon 31(3):165-180 
Vasanthakumar D., Roobakkumar A., Rahman V.J., Kumar P., Sundaravadivelan C., Babu A. 2012. Enhancement of the reproductive potential of Mallada boninensis Okamoto (Neuroptera: Chrysopidae), a predator of red spider mite infesting tea: an evaluation of artificial diets. Arch. Biol. Sci., Belgrade, 64 (1), 281-285, 2012 DOI:10.2298/ ABS1201281V 281
Wackers F.L., Romeis J., van Rijn P. 2007. Nectar and pollen-feeding by insect herbivores and implications for multitrophic interactions. Annu Rev Entomol 52:301-323

Zehnder G., Gurr G.M., Uhne S.K., Wade M.R., Wratten S.D., Wyss E. 2007. Arthropod pest management in organic crops. Annu Rev Entomol $52: 57-80$

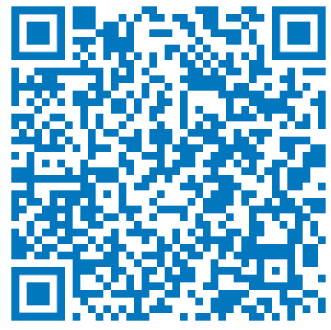

